\title{
Prognosis and Treatment of Ectopic Pregnancy at the University Hospital Center of Dakar
}

\author{
Koulimaya GCE, Diouf AA, Diallo M*, Niassy AC, Niass A, Sène C, Dia A and Diouf A \\ Obstetric gynecology Unit, Pikine National Hospital, Sénégal
}

Submission: April 15, 2018; Published: May 14, 2018

"Corresponding author: Moussa DIALLO, Obstetric gynecology Unit, Pikine National Hospital, located in Thiaroye Camp, Dakar, Sénégal, Tel: 33853 00 71; Fax: 3385300 69; Email: moussadiallo25@hotmail.com

\begin{abstract}
The objectives of this work were to evaluate the epidemiology, management and prognosis of ectopic pregnancy in our hospital.

Method: It wasa retrospective, descriptive and analytical study dealing with cases of extra-uterine pregnancies diagnosed in our hospital during the period extending from January 1, 2008 through December 31, 2014.

Results: The prevalence was estimated at $0.99 \%$. The average age of women in gestation was 29.47 years (extremes between 14 years and 46 years). The average parity was 1.84. 85.5\% among those women came from the Dakar suburbs and townships. The risk factors that were found can be stated as follows: pelvic genital infections (22.6\%), unconstrained abortion antecedents (22\%), contraception (19.3\%), tobacco addiction $(13 \%)$, infertility (4.3\%), Extra-uterine pregnancy antecedents $(2.7 \%)$ and one case of appendectomy $(0.5 \%)$. The average gestational age was 7 SA. The classical symptomatic triad, namely pelvic pains (94.6\%), amenorrhoea (92.5\%) and breakthrough bleeding $(76.3 \%)$, were observed in the majority of patients. Pelvic ultrasound allowed the diagnosis of ectopic pregnancy in $76 \%$ cases. Radical laparotomy surgery outstripped therapeutic management. Blood transfusion was carried out in 30.6\% cases. As regards ultimate fertility, 22\% expectant mothers eventually got pregnant.
\end{abstract}

Conclusion: The frequency of ectopic pregnancy at Pikine General Hospital remains very high. Prevention is essentially based on the fight against risk factors, namely genital infections. The education of populations to help raise their awareness as regards early consultation is fundamental, in order to prevent any diagnosis setback, which can be the source of instant, but also long-term complications. Medical nursing remains overshadowed by laparotomy in our regions where laparoscopic surgery is not widespread.

Keywords: Extra-uterine pregnancy; Ectopic pregnancy; Laparotomy surgery; Dakar

\section{Opinion}

Ectopic pregnancy (EP) is defined as the implantation and development of an egg outside the uterine cavity. The frequency of EP has doubled in the past 15 years (2\% of pregnancies, or 14,000 per year), coinciding with the upsurge in favoring factors such as salpingitis, tubal surgery and smoking. It ranks second in gynecological and obstetric emergencies after cesarean section in Senegal [1-4]. EP is a serious affection because it is still the leading cause of death in the first trimester of pregnancy and significantly compromises subsequent fertility. Much progress has been made in recent years to improve the management and prognosis of this disease, mainly in developed countries. Medical treatment and conservative laparoscopic surgery allow, in early forms, to improve overall management and subsequent fertility. In Senegal, little work has been done on the disease. This is why we conducted this study, the general objective of which was to improve the management of pregnant women admitted to GEU in our hospital.

\section{Methodology}

This was a descriptive and analytical retrospective study of cases of all cases of EP diagnosed in our center during the period from January 1, 2008 to December 31, 2014. Included were all patients who had been diagnosed with clinical EP and subsequently confirmed by pelvic ultrasound, qualitative or quantitative determination of the rate of $\beta$-HCG. The data were recorded with the software Sphinx Plus2 version 5.1.0.2, and analyzed with software SPSS version 20.0 and Microsoft Excel 2007.

\section{Results}

The prevalence was $0.99 \%$. The average age of gestants was 29.47 years (range 14 years and 46 years). The average parity was $1.84 .85 .5 \%$ of pregnant women came from the suburbs of Dakar. The risk factors found were: pelvic genital infections (22.6\%), previous history of spontaneous abortions (22\%), 
contraception (19.3\%), smoking (13\%), infertility (4\%), 3\%), antecedents of EP (2.7\%) and one case of appendectomy $(0.5 \%)$. Mean gestational age was 7 weeks. The classic symptomatic triad (pelvic pain (94.6\%), amenorrhoea (92.5\%) and metrorrhagia $(76.3 \%)$ was found in the majority of patients, and pelvic ultrasound EP in $76 \%$ of the cases. The radical surgery by laparotomy dominated the therapeutic management, a blood transfusion was performed in $30.6 \%$ of the cases, and $22 \%$ of pregnant women had to become pregnant.

\section{Discussion}

The incidence of EP in our series is consistent with that of the literature, which varies between 0.51 and $2 \%$. This impact could be explained by the recrudescence of the risk factors reported in the literature that are found in our study in $57.6 \%$ of cases. In our study, the average age of onset of EP was 29.4 years comparable to that reported by most authors. Which corresponds to the period of full sexual activity with the increase of the risk factors as Deshmukh supports it [1]. Sexual activity is often early in Africa as demonstrated by our study with extreme age of 14 , leading to say that the woman can present an EP at any age of her period of genital activity. In most studies, the EP was most often associated with low parity [2,3], which can be explained by the age of onset of the EP most often at the beginning of an obstetric career. In the literature, the main risk factors of the EP found in women without contraception are the history of genital infection or tubal surgery and smoking. Other risk factors are age of the woman, history of spontaneous miscarriage, progestational micro pills contraception and infertility [4,5]. These same risk factors were found in our study at more or less identical frequencies, but differences were noted for some factors including smoking, which was the second risk factor for EP in France [6,7] and was not found than in $3 \%$ of cases in our series.

The mean gestational age was 7 weeks, which is significantly lower than that found by other authors [8-10]. The circumstances of the diagnosis were almost represented by the symptomatic triad (94.6\% pelvic pain, 92.5\% secondary amenorrhoea and $76.3 \%$ metrorrhagia) in our series and in most African countries $[11,5]$. In our study, as in most African studies [4,5], the diagnosis of EP was usually made at the rupture stage, which explains why pregnant women presented a state of shock in $19.4 \%$ of cases, contrary to what is observed in industrialized countries where the haemodynamic status at the time of diagnosis is most often satisfactory because most EP are diagnosed before rupture. Ultrasonography was the most commonly performed paraclinical examination (79\%) exceeding the plasma BCG beta assay consistent with data from the African literature [2,12]. This being due to its greater accessibility in our regions, especially in the birth room.

In our study, management was dominated by laparotomy (96\%) with salpingectomy in $75.8 \%$, simply because of the frequency of the broken forms at the time of diagnosis. This radical surgery thus altering the subsequent fertility of these women. Only five pregnant women had received medical treatment with methotrexate for which failure was seen in two patients. The laparoscopic surgery described as the best method of taking care of the EP was practiced only slightly in our countries unlike the developed countries (more than 80\%). In our series, only two pregnant women had benefited from this laparoscopic surgery (1\%); Mbaye (Senegal) [13] had regained 4.6\%. This phenomenon is explained by the high cost of the installation of an endoscopic unit but also because of the delay of management, most of our patients $(76.3 \%)$ had a hemoperitoneum. The immediate maternal prognosis is generally good, no case of maternal death was recorded in our study against $2.6 \%, 1.2 \%$, $1.63 \%$ and $1.7 \%$ reported respectively by Moreau in 1995 [4] and Cisse in 2003 [14] in Dakar, Senegal, Nayama (in 2006) [2] in Niger and Sepou (in 2006) [15] in the Central African Republic. This could be explained by the management of patients who has improved both diagnostically and therapeutically. On the other hand, the subsequent fertility remains compromised in an African socio-cultural context where the means of medical assistance to procreation (AMP) are very limited.

\section{Conclusion}

The frequency of ectopic pregnancy at Pikine National Hospiatal remains high. Prevention is essentially based on the fight against risk factors, especially genital infections. Educating the population for early consultation is essential in order to avoid any delay in diagnosis that causes immediate but also long-term complications. Management is still dominated by laparotomy in our regions where coelio-surgery is not common.

\section{References}

1. Eshmukh JS, Zodpey SP, Vasudeo ND (1999) Risk factors for ectopic pregnancy: A case control study. Indian J of Community 24(2):58-63

2. Nayama M, Gallais A, Ousmane N, Idi N, Tahirou A, et al. (2006) Prise en charge de la grossesse extra-utérine dans les pays en voie de développement : exemple d'une maternité de référence au Niger. Gynecol Obstet Fertil 34 : 14-18.

3. Yao I, Doukoure B, Guie P, N'Guessen E, Bohoussou KPE, et al. (2009) Grossesses extra-utérines tubaires : aspects épidémiologiques et histopathologiques de 40 cas colliges a la maternité du CHU de Treichville (Abidjan-Cote d'Ivoire). Revue Bio-Africa 7: 44-49.

4. Moreau JC, Rupari L, Dionne P, Diouf A, Diouf F, et al. (1995) Aspects épidémiologiques et anatomo-cliniques des grossesses extra-utérines à Dakar. Dakar Med 40: 175-79.

5. Randriambololona DMA, Anjaharisoaniaina NT, Rekoronirina EB, Harioly MOJ, Randriambelomanana JA, et al. (2012) Grossesse extrautérine à Madagascar : 107 observations. Médecine et Santé Tropicales 22: 394-397.

6. Bouyer J (2003) Epidémiologie de la grossesse extra-utérine: incidence, facteurs de risque et conséquences. J Gynecol Obstet Biol Reprod 32(7): 8-17.

7. Monnier JC, Vantyghem A, Vantygem H, Lanciaux MC, Vinanier D, et al. (1985) aspects épidémiologiques, diagnostiques, thérapeutiques et Pronostiques: A propos de 117 observations relevées d'avril 1976 à septembre. J Gynecol Obstet Biol Reprod 14: 67-75. 
8. Meyé JF, Sima-Zue A, Sima-Olé B, Kendjo E, Engongah-Béka T, et al (2002) Aspects actuels de la grossesse extra-utérine à Libreville (Gabon) : à propos de 153 cas. Cahiers d'études et de recherches francophones / Santé 12(4): 405-408.

9. Pither S, Lawson MJM, Manou BLS, Tchantchou T, Igumu ON, et al (2010) Traitement cœlioscopique des grossesses extra-utérines : à propos de 107 cas colligés au service de chirurgie gynécologique de l’Hôpital 0. Bongo de Libreville (Gabon). J de la Sago 11(1): 1-6.

10. Dembele Y (2006) Grossesse extra-utérine : aspects épidémiologique, clinique thérapeutique et pronostique de la GEU dans le service de gynécologie obstétrique du centre de santé de référence de la commune $\mathrm{V}$ à propos de 128 cas. Thèse Med, Bamako n²42.

11. Diallo FB, Idi N, Vangeenderhuysen C (1998) La grossesse extrautérine à la maternité centrale de référence de Niamey (Niger) aspects diagnostiques, thérapeutiques et pronostiques. Med Afr Noire 45(6): 365-369.
12. Rafia M (2006) Prise en charge de la grossesse extra-utérine au service de gynéco-obstétrique « B » (à propos de 86 cas). Thèse Med, Casablanca $\mathrm{n}^{\circ} 27$

13. Mbaye $M$, Cissé ML, Guèye SMK, Dièmé FME, Diouf AA, et al. (2012) Premiers résultats de la cœlioscopie gynécologique au Centre hospitalier universitaire (CHU) de Dakar : Série prospective de 128 cas. J Obstet Gynecol Can 34(10): 939-946.

14. Cissé CAT, Badaoui EIB, Dieme FMÉ, Moreau JC (2003) Intérêt du minipfannenstiel dans le diagnostic précoce de la grossesse extra-utérine en milieu africain. Cahiers d'études et de recherches francophones/ Santé 13(3): 191-195.

15. Traoré Y, Teguete I, Thera AT, Mulbah JK, Kane F, et al. (2006) Association grossesse extra-utérine et intra-utérine: à propos de 3cas. Mali Med 21(4): 35-38.

\section{Your next submission with Juniper Publishers will reach you the below assets}

- Quality Editorial service

- Swift Peer Review

- Reprints availability

- E-prints Service

- Manuscript Podcast for convenient understanding

- Global attainment for your research

- Manuscript accessibility in different formats

( Pdf, E-pub, Full Text, Audio)

- Unceasing customer service

Track the below URL for one-step submission https://juniperpublishers.com/online-submission.php 